\title{
Study of sociodemographic profile and pattern of gynaecological malignancies in a tertiary care center
}

\author{
Sushila Chaudhary ${ }^{1}$, Savita Rani Singhal ${ }^{2}$, Latika ${ }^{3}$, Anjali Gupta ${ }^{4}$
}

Department of Obstetrics and Gynaecology, PGIMS, Rohtak, Haryana, India

Received: 03 June 2016

Accepted: 01 July 2016

\section{*Correspondence:}

Dr. Sushila Chaudhary,

E-mail: sushilachaudhary68@gmail.com

Copyright: (c) the author(s), publisher and licensee Medip Academy. This is an open-access article distributed under the terms of the Creative Commons Attribution Non-Commercial License, which permits unrestricted non-commercial use, distribution, and reproduction in any medium, provided the original work is properly cited.

\begin{abstract}
Background: Gynaecological malignancies are second most common cancer of females after cancer breast. Carcinoma cervix is the commonest gynaecological malignancy in developing countries while in developed countries, ovarian cancer is the commonest gynaecological malignancy. Appropriate screening and timely diagnosis can save many lives. The objective of this study was to study socio-demographic profile of patients presenting with gynaecological malignancy. And to study presenting symptoms and pattern of gynaecological malignancies in them

Methods: It was a retrospective record based study from December 2011 to December 2015. Various parameters from Case records of patients with gynaecological malignancies who visited outpatient department of unit IV were retrieved and analysis done.

Results: In our study, most of the patients (30.52\%) belonged to age group of 51-60 years, were multiparous $(94.21 \%)$, Illiterate $(67.3 \%)$ and belonged to rural background $(65.28 \%)$. Most of the patients of cancer cervix had their presenting complaint as post-menopausal bleeding (48.38\%), followed by excessive white discharge $(33.87 \%)$. Majority of patients $(65.26 \%)$ had cancer cervix, were in FIGO stage II .Commonest histopathological type was squamous cell carcinoma.

Conclusions: Most common gynaecological malignancy in India is carcinoma cervix. Proper screening and timely diagnosis can save many lives.
\end{abstract}

Keywords: Gynaecological malignancies, Cervical cancer, Ovarian cancer, Endometrial cancer

\section{INTRODUCTION}

Gynaecological malignancies are second most common cancer of females after cancer breast. ${ }^{1}$ Carcinoma cervix is the commonest gynaecological malignancy in developing countries while in developed countries, ovarian cancer is the commonest gynaecological malignancy. ${ }^{2}$ In India, around 800000 new cases of cancer are emerging every year, cancer cervix being the commonest gynaecological malignancy, followed by ovarian, endometrial, vaginal, vulva and gestational trophoblastic neoplasia. $70 \%$ of gynaecological malignancies are reported in advanced stage. Risk factors of cervical cancer are early marriage, early child birth, multiparity, poor genital hygiene, chronic pelvic infection with agents causing sexually transmitted diseases. ${ }^{3}$ Most of the cervical, vagina and vulval cancers are squamous cell carcinomas histopathologically and are radio sensitive tumors, whereas most of ovarian and endometrial cancers are adenocarcinomas, being less sensitive to radiation. Detailed history and proper clinical examination of every female coming to gynaecological out-patient department must be done to rule out any gynaecological malignancy. Every suspected case to be confirmed by biopsy of tissue concerned, as gold standard of diagnosis of any malignancy is tissue biopsy. ${ }^{4}$ Screening of cervical cancer is effective, but no screening test available for ovarian malignancy. Despite the available screening methods, most of the patients present late because of unawareness of symptoms. Advance stage 
of any malignancy reduces treatment modalities, decreases survival rate. Gynaecological malignancies are significant cause of morbidity and mortality in women throughout the world. ${ }^{5}$ Cancer cervix is the leading cause of death in women in developing countries. So appropriate screening and timely diagnosis can save many lives.

The objective of this study was to study sociodemographic profile of patients presenting with gynaecological malignancy. And to study presenting symptoms and pattern of gynaecological malignancies in them.

\section{METHODS}

It was a retrospective study carried out in the unit IV, department of obstetrics and gynaecology, of a leading tertiary and referral center in Haryana over a period of four years, from December 2011 to December 2015. Case records of patients with gynaecological malignancies who visited out-patient department of unit IV were retrieved and studied. Various parameters like, age, parity, residence, literacy status, presenting complaints, clinical staging, histopathological diagnosis and mode of treatment were analyzed in detail. Whole data was compiled and analysis done.

\section{RESULTS}

A total of 16,560 patients visited gynaecological outpatient department for various complaints during the study period from December 2011 to December 2015.A total of 190 patients of gynaecological malignancies were studied. In our study, most of the patients (30.52\%) belonged to age group of 51-60 years (Table 1). Majority of the patients were multiparous (94.21\%). Illiterate $(67.3 \%)$ and belonged to rural background (65.28\%) (Table 2 and 3). Out of total patients, $39.47 \%$ presented with complaints of post-menopausal bleeding, $23.15 \%$ patients presented with excessive white discharge, $14.73 \%$ of patients had abdominal distension, $8.421 \%$ had history of contact bleeding, $6.31 \%$ of patients complained of pain abdomen while $5.78 \%$ patients had menstrual irregularities.

Table 1: Distribution of gynaecological malignancies according to age of patient.

\begin{tabular}{|llllllll|}
\hline Age (years) & Cervix & Ovary & endometrium & vagina & vulva & Fallopian tube & Choriocarcinoma \\
\hline $20-30$ & $5(4 \%)$ & $3(7.14 \%)$ & 0 & 0 & 1 & 0 & 0 \\
\hline $31-40$ & $18(14.51 \%)$ & $10(23.80 \%)$ & 0 & $1(25 \%)$ & 0 & 0 & 1 \\
\hline $41-50$ & $39(31.45 \%)$ & $8(19.04 \%)$ & $4(26.67 \%)$ & $1(25 \%)$ & 1 & 1 & 0 \\
\hline $51-60$ & $40(32.26 \%)$ & $9(21.42 \%)$ & $7(46.67 \%)$ & $2(50 \%)$ & 0 & 0 & 0 \\
\hline $61-70$ & $14(11.29 \%)$ & $11(26.19 \%)$ & $2(13.33 \%)$ & 0 & 1 & 0 & 0 \\
\hline$\geq 71$ & $8(6.45 \%)$ & $1(2.38 \%)$ & $2(13.33 \%)$ & 0 & 0 & 0 & 0 \\
\hline
\end{tabular}

Table 2: Distribution of patients according to parity.

\begin{tabular}{|lllllll|l|}
\hline Parity & Cervix & Ovary & Endometrium & Vagina & vulva & fallopian tube & Choriocarcinome \\
\hline Nulliparous & 0 & $1(2.38 \%)$ & $2(13.33 \%)$ & 0 & 0 & 0 & $0-$ \\
\hline P1 & $2(1.61 \%)$ & $3(7.14 \%)$ & $3(20 \%)$ & 0 & 0 & 0 & 0 \\
\hline P2 and more & $122(98.38 \%)$ & $38(90.47 \%)$ & $10(66.66 \%)$ & 4 & 3 & 1 & 1 \\
\hline
\end{tabular}

Table 3: Patient profile.

\begin{tabular}{|lll|}
\hline Literacy status & No of patients & Percentage \\
\hline Illiterate & 128 & $67.3 \%$ \\
\hline Literate & 62 & $32.63 \%$ \\
\hline Back ground & No of patients & Percentage \\
\hline Rural & 125 & $65.78 \%$ \\
\hline Urban & 65 & $34.21 \%$ \\
\hline
\end{tabular}

Most of the patients of cancer cervix had their presenting complaint as post-menopausal bleeding (48.38\%), followed by excessive white discharge (33.87\%). Majority of patients with ovarian cancer presented with abdominal distension (66.6\%) and pain abdomen (28.57\%). $80 \%$ of patients with carcinoma endometrium presented with post-menopausal bleeding followed by rest who had other menstrual irregularities. In patients with cancer vagina, $50 \%$ had come to OPD with complaints of post-menopausal bleeding while, rest had complaints of excessive vaginal discharge. Out of total 3 patients of cancer vulva, $2(66.6 \%)$ had vulval pruritus while another one patient came with complaint of vulval growth. Patient who was diagnosed as having fallopian tube cancer later on also presented with post-menopausal bleeding and one patient with chorio-carcinoma had complained of menstrual irregularities (Table 4). 
Table 4: Distribution of gynaecologic malignancies according to presenting complaints.

\begin{tabular}{|c|c|c|c|c|c|c|c|}
\hline $\begin{array}{l}\text { Presenting } \\
\text { complaints }\end{array}$ & cervix & Ovary & Endometrium & Vagina & Vulva & Fallopian tube & Choriocarcinoma \\
\hline $\begin{array}{l}\text { Post- } \\
\text { menopausal } \\
\text { bleeding }\end{array}$ & $60(48.38 \%)$ & 0 & $12(80 \%)$ & $2(50 \%)$ & 0 & 1 & 0 \\
\hline $\begin{array}{l}\text { Abdominal } \\
\text { distension }\end{array}$ & 0 & $28(66.66 \%)$ & 0 & 0 & 0 & 0 & 0 \\
\hline Pain abdomen & 0 & $12(28.57)$ & 0 & 0 & 0 & 0 & 0 \\
\hline $\begin{array}{l}\text { Excessive } \\
\text { vaginal } \\
\text { discharge }\end{array}$ & $42(33.87 \%)$ & 0 & 0 & $2(50 \%)$ & 0 & 0 & 0 \\
\hline $\begin{array}{l}\text { Menstrual } \\
\text { irregularities }\end{array}$ & $5(4.03 \%)$ & $2(4.76 \%)$ & $3(20 \%)$ & 0 & 0 & 0 & 1 \\
\hline $\begin{array}{l}\text { Contact } \\
\text { bleeding }\end{array}$ & $16(12.90 \%)$ & 0 & 0 & 0 & 0 & 0 & 0 \\
\hline Vulval pruritis & 0 & 0 & 0 & 0 & $2(66.66 \%)$ & 0 & 0 \\
\hline Vulval growth & 0 & 0 & 0 & 0 & $1(33.33 \%)$ & 0 & 0 \\
\hline $\begin{array}{l}\text { Incontinence } \\
\text { of urine }\end{array}$ & $1(0.80 \%)$ & 0 & 0 & 0 & 0 & 0 & 0 \\
\hline
\end{tabular}

Table 5: Distribution of ca cervix patients according to FIGO staging.

\begin{tabular}{|llll|}
\hline \multicolumn{2}{|c|}{ Clinical stage of ca cervix } & $\begin{array}{l}\text { No of } \\
\text { patients }\end{array}$ & Percentage \\
\hline \multirow{2}{*}{ Stage I } & I a & 2 & 1.61 \\
\cline { 2 - 4 } & I b & 1 & 0.80 \\
\hline \multirow{2}{*}{ Stage II } & II a & 25 & 20.16 \\
\cline { 2 - 4 } & II b & 51 & 40.32 \\
\hline Stage III & & 43 & 34.68 \\
\hline Stage IV & & 2 & 1.61 \\
\hline Total & & $\mathbf{1 2 4}$ & $\mathbf{1 0 0}$ \\
\hline
\end{tabular}

Table 6: Relative frequency of gynaecological malignancies.

\begin{tabular}{|lll|}
\hline Site of malignancy & $\begin{array}{l}\text { No of } \\
\text { patients }\end{array}$ & Percentage \\
\hline Ca cervix & 124 & 65.26 \\
\hline Ca ovary & 42 & 22.11 \\
\hline Ca endometrium & 15 & 7.89 \\
\hline Ca vagina & 4 & 2.11 \\
\hline Ca vulva & 3 & 1.58 \\
\hline Ca fallopian tube & 1 & 0.53 \\
\hline Choriocarcinoma & 1 & 0.53 \\
\hline Total & $\mathbf{1 9 0}$ & $\mathbf{1 0 0}$ \\
\hline
\end{tabular}

Table 7: Distribution of patients according to histopathological examinations.

\begin{tabular}{|llllllll|}
\hline $\begin{array}{l}\text { Histo- } \\
\text { pathological type }\end{array}$ & Cervix & Ovary & Endometrium & Vagina & vulva & $\begin{array}{l}\text { Fallopian } \\
\text { tube }\end{array}$ & Choriocarcinoma \\
\hline $\begin{array}{l}\text { Squamous cell } \\
\text { carcinoma }\end{array}$ & $121(97.58 \%)$ & 0 & $1(6.67 \%)$ & 4 & 3 & 0 & 0 \\
\hline Adenocarcinoma & $3(2.42 \%)$ & $41(97.61 \%)$ & $14(93.33 \%)$ & 0 & 0 & 1 & 0 \\
\hline Dysgerminoma & 0 & $1(2.38 \%)$ & 0 & 0 & 0 & 0 & 0 \\
\hline
\end{tabular}

Out of total patients studied, $65.26 \%$ of patients had cancer cervix followed by ovarian $(22.11 \%)$, endometrial $(7.89 \%)$, vaginal $(2.11 \%)$, vulval $(1.58 \%)$, fallopian tube $(0.53 \%)$, choriocarcinoma $(0.53 \%)$ respectively. After examining patients with cancer cervix and after doing clinical staging, it was found that majority of patients were in FIGO stage II followed by $34.68 \%$ who belonged to stage III (Table 5, 6).
Commonest histopathological type came out to be squamous cell carcinoma $(100 \%$ each in vulval and vaginal cancer, $97.58 \%$ in cancer cervix, $6.66 \%$ in endometrial cancer), adenocarcinoma (100\% fallopian tube cancer, $97.67 \%$ of ovarian cancer and $93.3 \%$ of carcinoma endometrium, $2.42 \%$ of cancer cervix). One patient of ovarian dysgerminoma reported with pregnancy. Most of the patients of cancer cervix were in 
stage II, III, IV so referred to radiotherapy for treatment and all patients of cancer vagina and vulva were referred to radiotherapy. Surgery done in most of the patients of ovarian cancer and cancer endometrium.

\section{DISCUSSION}

Gynaecological malignancies are an important cause of morbidity and mortality in females these days. Cancer cervix tops the list of gynaecological malignancies despite the fact that it is preventable. Incidence of gynaecological malignancies in our study was $1.15 \%$.In present study $4.73 \%$ of total gynaecological malignancies reported in less than 30 age group while study of Kamath reported $14.2 \%$ gynaecological malignancies in less than 35 years age group, cause quoted by him being more female population in this age group. ${ }^{6}$ In our study percentage of rural, illiterate, multiparous females were more and these females are high risk for cervical malignancy due to early marriage, low socio-economic condition and lack of awareness for screening similar to study of Adamou who reported lack of awareness, noneducation as cause of delay in presentation of gynaecological malignancies. In was observed that postmenopausal bleeding is the commonest presenting complaint $(39.47 \%)$, followed by excessive white discharge, abdominal distension, contact bleeding $(23.15 \%, 14.74 \%, 8.42 \%$ respectively) while study of Sarkar et al reported excessive, offensive with or without blood stained vaginal discharge as the most frequent symptom $(69.0 \%)$ followed by irregular, heavy or prolonged vagina bleeding $(36.3 \%)$ and post-menopausal bleeding $(31.9 \%){ }^{7,8}$ In present study cancer cervix is the commonest gynaecological malignancy (65.26\%) followed by ovarian (22.11\%), endometrial (7.89\%), vaginal $(2.11 \%)$, almost similar to study of Sarkar et al who reported frequency of cervical malignancy (61.9\%), ovarian malignancy $(23.9 \%)$, while study of Y Jhansivani reported cancer cervix $(86.1 \%)$ and cancer ovary $(4.68 \%)$ in their studies but study of Nasreen reported ovarian cancer more than cervical cancer in his study $48 \%, 24 \%$ respectively)., ${ }^{2,9}$ It was found that most of cervical carcinoma cases reported in stage II, stage III and stage IV $(97.59 \%)$ and only $2.42 \%$ patients were in stage I similar to studies of Jhansivani Y, Sarkar et al and Agarwal. ${ }^{8-10}$ In all these studies, gynaecological malignancies were reported in advance stages. In present study most common histological type is squamous cell carcinoma which was seen in $97.58 \%$ cases of carcinoma cervix and $6.67 \%$ cases of carcinoma endometrium, all vaginal and vulval cancers, while $97.61 \%$ ovarian, $93.33 \%$ endometrial and $3.42 \%$ cervical carcinoma were adenocarcinoma, almost similar results were observed by study of Sarkar et al and Hopkins MP et al but later study was of ca cervix only. ${ }^{8,11}$ Most of the patients of cancer cervix in present study were referred to radiotherapy due to presentation in advance stage.

\section{CONCLUSION}

Most common gynaecological malignancy in India is carcinoma cervix .Most of the gynaecological malignancies is reported in advanced stage. In India lack of awareness and limited resources play an important role. More efforts are needed to increase the awareness in general population regarding common abnormal presenting symptoms. Proper screening, timely diagnosis and treatment can save many lives.

\section{Funding: No funding sources}

Conflict of interest: None declared

Ethical approval: The study was approved by the Institutional Ethics Committee

\section{REFERENCES}

1. Ejeckam GC, Abdullah F, Sakka EM, Dauleh W, Haseeb F. Gynaecological malignancy in Qatar. Eas t Afi Med J. 1994;71(2):777.

2. Nasreen F. Pattern of gynaecological malignancies in tertiary hospital. J Postgrad Med Inst. 2002;16:21520.

3. Devi KU. Current status of gynaecological cancer care in India. J Gynecol Oncol. 2009;20:77-80.

4. Brand AH. The woman with postmenopausal bleeding. Aust Fam Physician. 2007;36:116-20.

5. Siyal AR, Shaikh SM, Balouch R, Surahio AW. Gynaecological cancera histopathological experiences at Chandka Medical College and Hospital Larkana. Med Channel. 1999;5:15-9.

6. Anagha K, Radha R. Retrospective study of gynaecological malignanciesin less than 35 years of age in Southern India. JOCDR. 2011;5(6):1251-55.

7. Natalia A, Aliyu UU. Delayed presentation of patients with gynaelcological malignancies in Kano, North- Western Nigeria. J Obstet Gynecol. 2015;5:333-40.

8. Madhutandra S, Konar H, Raut D. Clinicopathological features of gynaecological malignancies in a tertiary care hospitalin Eastern India. Importance of strengthening primary health care in prevention and dection. Asian Pac J Prev. 2013;14(6):3541-45.

9. Jhansivani Y, Swaroopa R. Epidemiology of gynaelogical cancers in a tertiary care center Guntur. IOSR-JDMS. 2015;14(90):41-5.

10. Agarwal S, Malhotra KP, Sinha S, Rajaram S. Profile of gynaecological malignancies reported at a tertiary care center in India over the past decade; comparative evaluation with international data. Indian J Cancer. 2012;48:298-302.

11. Hopkins MP, Morley GW. A cmparision of adenocarcinoma and sq. cell carcinoma of cervix. Obstet Gynecol. 1991;77:912.

Cite this article as: Chaudhary S, Singhal SR, Latika, Gupta A. Study of sociodemographic profile and pattern of gynaecological malignancies in a tertiary care center. Int J Reprod Contracept Obstet Gynecol 2016;5:2640-3. 